\title{
Tantangan Dakwah di Era Milenial
}

\author{
Syamsuriah \\ Email : syamsuriahriah@yahoo.com
}

\begin{abstract}
Abstrak
Dalam ajaran Islam, hal yang tidak boleh berhenti untuk dilaksankan oleh para penganutnya adalah mengajak umat manusia kejalan kebaikan dan mencegah melakukakan hal-hal yang buruk yang paling dikenal menegakkan amal makruf dan nahi mungkar ,untuk menjalankan hal ini, bagaimana menghadapi tantangan dakwah di era mellineal ini,dengan membekali diri dan menyesuaikan diri untuk sebisa mungkin mengusai tekhnologi, media social dan internet. Karena dakwah bisa mudah ditermah karena sekarang pada umumnya setiap individu bergangtung pada alat komunikasi gajet, yang akses dakwah mudah didapat di internet.
\end{abstract}

Kata kunci : Dakwah Islam, Tatangan Era Millineal.

\section{Pendahuluan}

Pengertian generasi millennial atau disebut juga generasi $\mathrm{Y}$ adalah generasi setelah generasi X, yang lahir di antara tahun 1980an hingga 2000an. Saat ini usia mereka berada di pertengahan 20 tahun dan pertengahan 30 tahun. Kini mereka menempati posisi terbesar kedua dalam jumlah terbanyak yang berada di dalam dunia kerja di Indonesia, yaitu berjumlah empat puluh persen.

Masa sekarang ini adalah masa yang sangat istimewa di mana semua orang bisa mendapatkan dan mengerjakan sesuatu dengan sangat mudah. Mungkin di zaman sebelum penemuan media elektrnonik, orang tersebut memerlukan berbagai kitab atau buku bacaan, tetapi di era mellineal semua informasi bisa didapatkan dengan sangat mudah, melalui internet.

Perubahan globalisasi sangat pesat menuntut orang tidak mesti menguasai referensi berupa buku.Tetapi beralih bagaimana mereka bisa mengesuai tekhnologi for and zero Sedangkan di era Millenial, digital merupakan kebutuhan yang utama, orang tinggal mencari sesuatu yang diinginkan di salah satu situs internet. Era millennial ini adalah puncak dimana semuanya yang serba instan dan banyak dinikmati oleh masyarakat. Sekarang da`i (mubaligh) pun dituntuk untuk menguasai Semua informasi yang diperlukan akan muncul dengan berbagai model. media tekhnologi agar sasaran dakwah bisa sampai kepada khalayak banyak dengan mudah. Berdakwah atau menyampaikan dakwahnya melalui media-media yang ada seperti berdakwah dengan media televisi, media social yang diapload melalui hand phon/ gedget dan juga media tulisan. Realitas yang ada banyak sekali da`i yang sudah memanfaatkannya terutama dalam pertelevisian. Dan media social serta internet, terkadang terfikirkan ternyata tidak hanya artis saja yang ingin viral dimedia social atau di internet, bahkan para da i pun juga banyak, hingga menjamur dimana-mana. Efek positifnya ketika bertujuan untuk menegakkan ajaran, dan syariatnya tetapi apakah itu saja kenyataannya.

DOI:Xxx-xxx

Jurnal Ilmiah Islamic Resources FAI-UMI Makassar | 164 
Diera ini mereka medapatkan perilaku yang nyaman, rasa tentram karena fasilitas yang ada. Pada umumnya, dakwah yang dilaksanakan dalam sebuah majelis taklim di sebuah surau, masjid atau musholla berlangsung dalam suasana sakral dan khidmat. Kemajuan teknologi dan informasi, memungkinkan seorang da'i untuk berimprovisasi dengan selingan humor dan hal-hal lain, agar materi ceramahnya tetap menarik untuk disimak. Mengingat tantangan dakwah diera teknologi dan informasi, khususnya media memang tidak bisa dilepaskan dari wahana hiburan. Dampaknya, orientasi dakwah yang diperankan para da'i, juga semakin berkembang, bahkan cenderung menjadi bias. Semula, dakwah yang lebih banyak bersentuhan dengan ranah ibadah, selalu dilandasi dengan niat dan motivasi untuk beribadah pula, yakni dilaksanakan dengan penuh suka cita, hati yang ikhlas dan hanya mengharap ridha Allah Swt semata. Namun, dalam perkembangannya pola berdakwah melalui media social sebagai wujud kemajuan teknologi menjadi tantangan bagi tersendiri bagi seseorang da'i. Pengaruh media sosial memungkinkan seorang da'i popularitas dimata pemirsanya seperti layaknya para publik figure yang sangat dikenal melaui youtober.dan sebaiknya untuk menaikkan popularitasnya seorang dai atau pendakwah seharusx Dai memiliki kemampuan menyajikan dakwah atau memyampaikan dakwahnya melalui youtober dan media social lainnya.

\section{Rumusan Masalah}

Berdasarkan pendahuluan diatas, maka rumusan masalah penulisan ini, adalah bagaimana menghadapi tatangan dakwah di era milenial.

\section{Pembahasan}

\section{Pengertian Dakwah}

Pengertian Dakwah Islam adalah agama dakwah, maksudnya sebagai risalah dari Allah yang diberikan kepada Nabi Muhammad SAW untuk mengajak seluruh umat manusia. Berdasarkan akar kata (etimologi) kata dakwah merupakan bentuk masdar dari kata yad'u (fiil mudhari) dan da'a (fiil madhi) yang artinya adalah memanggil (to call), mengundang, mengajak (to invite), mendorong (to urge) dan memohon (to pray) (Supena, 2007: 105). Dakwah secara terminologi mengandung beberapa arti yang beraneka ragam. Banyak ahli ilmu dakwah dalam memberikan 20 pengertian atau definisi terhadap istilah dakwah terdapat beberapa pendapat, diantaranya :

1. Menurut Asep Muhiddin memberikan definisi bahwa dakwah adalah upaya kegiatan mengajak atau menyeru umat manusia agar berada di jalan Allah yang sesuai fitrah dan kehanifannya secara integral (Asep Muhiddin, 2002: 19).

2. Menurut Amrullah Ahmad (1983: 17) memberikan definisi dakwah adalah mengadakan dan memberikan arahan perubahan, merubah struktur masyarakat dan budaya dari kedhaliman ke arah keadilan, kebodohan kearah kemajuan (kecerdasan), kemiskinan ke arah kemakmuran, keterbelakangan ke arah kemajuan yang semuanya dalam rangka meningkatkan derajat manusia dan masyarakat ke arah puncak kemanusiaan.

3. Menurut Dzikron Abdullah dakwah adalah semua usaha untuk menyebarluaskan Islam dan merealisasikan ajaranya di tenga $\mathrm{h}$ masyarakat dan kehidupanya agar mereka memeluk agama Islam dan mengamalkannya dengan baik (Abdullah, 1989: 7) 
4. Hamzah Ya'qub memberikan pengertian dakwah Islam adalah mengajak umat manusia dengan hikmah kebijaksanaan untuk mengikuti petunjuk Allah dan Rasul-Nya (Ya'qub, 1981: 13).

5. Menurut Isa Anshary, istilah dakwah itu menyampaikan seruan Islam, mengajak dan memanggil umat manusia, agar menerima dan mempercayai keyakinan dan pandangan hidup Islam (Isa Anshary, 1979: 17).

6. Menurut Asmuni Syukir, memberikan definisi bahwa dakwah adalah suatu usaha mempertahankan, melestarikan dan menyempurnakan umat manusia agar mereka tetap beriman kepada Allah, dengan menjalankan syariat-Nya sehingga mereka menjadi manusia yang hidup bahagia di dunia maupun akhirat (Syukir, 1983: 20). Dari beberapa definisi dakwah tersebut dapat disimpulkan bahwa dakwah memiliki makna sebagai sebuah usaha menyeru ataupun mengajak seluruh manusia kepada ajaran Islam serta menerapkan dalam segala aspek kehidupannya agar Undang-Undang Ilahi tegak dan menjadi pewarna dasar bagi sikap dan prilaku manusia dalam kehidupan dan pergaulan untuk mencapai dunia akhirat.

Tujuan Dakwah Setiap orang yang mengerjakan sesuatu haruslah mengetahui tujuan yang hendak dicapai. Demikianlah da'i harus pula mengerti dengan jelas tentang tujuan dakwahnya. Pengertian akan tujuan itulah yang akan menjadi sasaran dan menjadi pengarah daripada tindakan (Dzikron Abdullah, 1989: 153). Tujuan dakwah ini selanjutnya dapat diklasifikasikan menjadi tujuan umum dan khusus.

\section{Tujuan umum}

Menurut Awaludin Pimay dalam bukunya "Metodologi Dakwah" tujuan dakwah secara umum adalah menyelamatkan umat manusia dari lembah kegelapan dan membawanya ketempat yang terang benderang, dari jalan yang sesat kepada jalan yang lurus, dari lembah kemusyrikan dengan segala bentuk kesengsaraan menuju kepada tauhid yang menjanjikan kebahagiaan (Awaludin Pimay, 2006: 8) Pemahaman terhadap tujuan dakwah semacam ini tercermin dalam firman Allah dalam Q.S. Al-Thalaq ayat 11 Artinya :

Dan mengutus seorang Rasul yang membacakan kepadamu ayat-ayat Allah yang menerangkan (bermacam-macam) supaya Dia mengeluarkan orangorang yang beriman dan beramal saleh dari kegelapan kepada cahaya (Depag RI, 1989 : 947).

\section{Tujuan khusus}

Tujuan khusus dakwah merupakan perumusan tujuan sebagai perincian dari pada tujuan umum dakwah. Tujuan ini dimaksudkan agar dalam pelaksanaan seluruh aktifitas dakwah jelas diketahui ke mana arahnya ataupun jenis kegiatan apa yang hendak dikerjakan. Tujuan khusus dakwah secara operasional dibagi ke dalam beberapa tujuan (lebih khusus) yakni :

Mengajak umat manusia yang sudah memeluk agama Islam untuk selalu meningkatkan taqwanya kepada Allah SWT. Membina mental agama (Islam) bagi kaum yang masih muallaf. Mengajak umat manusia yang belum beriman agar beriman kepada Allah SWT (memeluk agama Islam). Mendidik dan mengajar anak-anak agar tidak menyimpang dari fitrahnya (Asmuni Syukir, 1983: 54).

DOI:xxx-xxx 
Dakwah merupakan seruan atau ajakan kepada keinsafan setiap manusia atau usaha mengubah situasi, kepada situasi yang lebih baik dan sempurna, baik terhadap pribadi maupun masyarakat. Perwujudan dakwah bukan sekadar usaha peningkatan pemahaman keagamaan dalam tingkah laku dan pandangan hidup saja, tetapi juga menuju sasaran yang lebih luas. Apalagi pada masa sekarang ini, dakwah harus lebih berperan menuju kepada pelaksanaan ajaran Islam secara lebih menyeluruh dalam berbagai aspek kehidupan. Pada kenyataannya dakwah Islam itu tidak bebas dari berbagai kendala dan tantangan. Realitas dakwah Islam menjadi problem keagamaan yang krusial dan terkadang dilematis. Terlebih lagi, bila kita mengamati dakwah Islam diera teknologi dan informasi seperti sekarang ini, maka tantangan dan kendalanya akan semakin kompleks. Dewasa ini, setidaknya tantangan dakwah Islam tersebut berkaitan dengan ekses globalisasi dan kenyataan pluralitas agama. Kemajuan pesat iptek telah mentransformasikan peradaban manusia dari kultur pertanian ke industri kemudian ke abad informasi dan komunikasi. Kosa kata dan sekaligus senjata yang begitu signifikan dan determinan diera globalisasi saat ini adalah kecanggihan teknologi informasi dan komunikasi, Melalui jaringan teknologi informasi dan komunikasi di era globalisasi terus merambah ke segenap penjuru dunia. Sehingga realitas dunia sekarang dengan segala kemajemukan kesenjangan dan ironinya telah menjadi sekat-sekat sosiokultural bangsa dan mengaburkan batas-batas geografis negara. Berbagai masalah yang timbul karena pengaruh era teknologi dan informasi, di antaranya: Pertama, budaya dan gaya hidup serba seragam dengan tanpa mempertimbangkan urgensinya, seperti pada menu makan, mode pakaian dan kesenangan hiburan. Kedua, infiltrasi budaya dan tata nilai asing yang lebih intens dan masif yang banyak bertentangan dengan identitas kepribadian bangsa dan moral agama, seperti melalui televisi dan film media sosial. Ketiga, dengan mengutip Mike Featherstone, adalah merebaknya konsumtivisme yang menggiring umat manusia kepada pemiskinan spiritual dan falsafah hidup hedoinistik. (Asep Muhyiddin, 2002 : 65).

Secara harfiah dakwah merupakan masdar dari fi'il (kata kerja) da'a dengan arti ajakan, seruan, panggilan, undangan. Selain itu terdapat varian makna dari etimologi dakwah. Dakwah dapat berarti do'a atau lainnya. Dalam kajian ini, wacana dibatasi pada makna dakwah yang barkaitan dengan tugas Nabi Muhammad sebagai da'i atau sahib ad-da'wah. Pembatasan ini berkaitan dengan ruang lingkup yang telah ditunjukkan oleh ayat-ayat al Qur'an maupun hadis untuk kepentingan pelaksanaan da'wah islamiyah. Secara etimologi, kata dakwah sebagai bentuk masdar dari kata (fiil madzi) dan (fi'il mudhari') yang artinya adalah memanggil (to call), mengundang (to invite), mendorong (to urge) dan memohon (to pray). Berdakwah berarti menyampaikan sesuatu kepada orang lain yang besifat mengajak untuk merubah suatu keadaan yang tidak baik kepada yang baik dan terpuji. Secara terminologi, banyak pendapat tentang definisi dakwah, antara lain: Syeikh Ali Makhfuz.

Pendapat Syeikh Ali Makhfuz dalam kitabnya Hidayat al Mursyidin, bahwa dakwah mendorong manusia agar memperbuat kebaikan dan menurut petunjuk, menyeru mereka berbuat kebajikan dan melarang mereka dari perbuatan mungkar, agar mereka mendapat kebahagiaan di dunia dan akhirat. (Syeikh Ali Makhfuz, 1970 : 26).

Menurut Muhammad Nasir, dakwah adalah usaha menyerukan dan menyampaikan kepada perorangan manusia dan seluruh umat tentang pandangan dan tujuan hidup manusia di dunia ini, yang meliputi amar ma'ruf nahi munkar, dengan berbagai macam media dan 
cara yang diperbolehkan akhlak dan membimbing pengalamannya dalam perikehidupan. (Muhammad Nasir, $1971: 25$ ).

Dakwah berarti segenap aktifitas muslim, baik secara individual maupun kolektif, untuk mengkonstruksi masyarakat sesuai petunjuk Allah dan Rasul-Nya, dan aktifitas tersebut tidak terlepas dari lingkungan amar makruf dan nahi munkar. Secara umum, definisi dakwah yang dikemukakan para ahli menunjuk pada kegiatan yang bertujuan perubahan positif dalam diri manusia. Perubahan positif ini diwujudkan dengan peningkatan iman, mengingat sasaran dakwah adalah iman. Dakwah sering dipahami sebagai upaya untuk memberikan solusi Islam terhadap berbagai masalah dalam kehidupan. Untuk itu dakwah harus dikemas dengan cara yang menarik dan tampil secara aktual, faktual, dan kontekstual. Di mana aktual berarti dapat memecahkan masalah-masalah yang kekinian dan hangat di tengah masyarakat. Faktual berarti konkret dan nyata, sedangkan kontekstual dalam arti relevan dan menyangkut problema yang sedang dihadapi oleh masyarakat. Agama Islam sebagai suatu ajaran tidaklah berarti, manakala manusia tidak dimanifestasikan dalam perbuatan amalia. Ini dikarenakan agama tersebut, bukanlah agama yang semata-mata menyoroti satu sisi dari kehidupan manusia saja, akan tetapi Islam meliputi dan menyoroti semua persoalan hidup manusia secara total. Pengertian dakwah tidak lain adalah komunikasi, hanya saja yang secara khas dibedakan dari bentuk komunikasi yang lainnya terletak pada cara dan tujuan yang akan dicapai. Didalam komunikasi mengharapkan adanya partisipasi dari komunikan atas ide-ide atau pesan-pesan yang disampaikan oleh pihak komunikator sehingga dengan pesan-pesan yang disampaikan tersebut terjadilah perubahan sikap dan tingkahlaku yang diharapkan. Dakwah merupakan proses komunikasi, tetapi tidak semua proses komunikasi merupakan proses dakwah. (Saifullah, $2006: 54$ )

Kegiatan dakwah akan dapat berjalan secara efektif dan efisien harus menggunakan cara-cara yang strategis dan tepat dalam menyampaikan ajaran-ajaran Allah swt. Salah satu aspek yang bisa ditinjau adalah dari segi sarana dan prasarana dalam hal ini adalah media dakwah, karena dakwah merupakan kegiatan yang bersifat universal yang menjangkau semua segi kehidupan manusia, maka dalam penyampaiannya pun harus dapat menyentuh semua lapisan atau tingkatan baik dari sudut budaya, sosial, ekonomi, pendidikan dan kemajuan teknologi lainnya. Seiring dengan kemajuan teknologi, sehingga cara berdakwah pun sekarang mengalami perkembangan. Dakwah tidak lagi dilakukan secara sederhana tdak hanya sebatas diatas mimbar, di masjid-masjid atau mushalah tetapi mulai memanfaatkan kemajuan media teknologi. Hal ini dilakukan agar dakwah lebih meluas dan agar dakwah bisa dilakukan lebih efektif. Dakwah bisa dilakukan melalui media massa dan diterima oleh orang banyak. Karena sifatnya massal maka penerima pesan dakwah tidak hanya dikalangan tertentu saja. Kalangan yang dijangkau bisa luas begitu pula dampak yang ditimbulkannya. Oleh karena itu, kini berdakwah mempunyai tantangan sendiri. Media komunikasi dalam berdakwah pun terbagi menjadi dua yaitu, memanfaatkan jalur cetak. Selain itu ada pula yang bersifat elektronik, yang merupakan implikasi dari kemajuan media teknologi. Media komunikasi cetak misalnya surat kabar, majalah, selembaran dan lain sebagainya. Sedangkan media komunikasi elektronik misalnya pesawat televisi, dan yang paling mutakhir adalah internet. Dakwah Islam sebagai konsep maupun sebagai aktifitas telah memasuki seluruh wilayah dan ruang lingkup kehidupan manusia, sehingga seluruh aspek kehidupan tidak

DOI: $x x x-x x x$ 
dapat dilepaskan dari sudut pandang dakwah itu sendiri. Sejalan dengan pengertian dakwah sebagai nila-nilai Islam kedalam semua aspek kehidupan manusia. Lebih lanjut ia tegas bahwa makna dakwah itu sendiri tidak hanya sebatas tabligh seperti yang berlangsung dan mendominasi aktifitas dakwah selama ini. Dakwah melalui internet dan media sosial, yang merupakan suatu inovasi terbaru dalam syiar Islam, dan tentunya akan memudahkan para da'i dalam melebarkan sayap-sayap dakwahnya. Penggunaan media internet sebagai media dakwah merupakan kesempatan dan tantangan untuk mengembangkan dan memperluas cakrawala dakwah Islamiyah. Kesempatan yang dimaksud ialah bagaimana orang-orang yang peduli terhadap kemampuan dakwah maupun memanfaatkan media internet tersebut sebagai sarana dan media dakwah untuk menunjang proses dakwah Islamiyah. Sementara mewujudkannya mulai dari tenaga, pikiran dan sumber daya manusia yang mengerti akan dakwah dan internet. Umat Muslim harus mampu menguasai dan memanfaatkan sebesarbesarnya perkembangan teknologi informasi, "Dari sisi dakwah, kekuatan internet sangat potensial untuk dimanfaatkan. Tantangan Problematika Dakwah Tantangan dakwah beraneka ragam bentuknya, selama ini kita mengenal dalam bentuk klasik, bisa pada penolakan, cibiran, cacian, ataupun teror bahkan sampai pada tataran fitnah. Banyak para da'i mampu mengatasi tantangan atau rintangan tersebut dengan baik baik karena niatnya memang telah kuat sebagai pejuang. Meski demikian, ada pula yang tidak mampu untuk mengatasinya sehingga tersingkir dari kancah dakwah. Jalan dakwah bukan rentang yang pendek dan bebas hambatan, bahkan jalan dakwah sebenarnya penuh dengan kesulitan, amat banyak kendala dengan jarak tak terkira jauhnya. Tabiat ini perlu diketahui dan dikenali setiap aktivitas dakwah, agar para juru dakwah bersiap diri menghadapi segala kemungkinan yang akan terjadi diperjalanan sehingga revolusi informasi dan komunikasi di jalan dakwah bisa kita atasi. Allah swt. Telah memberikan rambu-rambu kepada kita tentang hal ini: "Apakah manusia mengira bahwa mereka sedang dibiarkan (saja) mengatakan, "Kami telah beriman," sedang mereka diuji lagi? Sesungguhnya kami telah menguji orang sebelum mereka, maka sesungguhnya Allah mengetahui orang-orang yang benar dan sesungguhnya Ia mengetahui orang yang berdusta." (al-Ankabut: 2-3).

Ujian tersebut sesunggunya diperlukan oleh orang-orang mukmin justru untuk meningkatkan kapasitasnya. Adanya ujian dan kendala-kendala riil ditengah kehidupan ini akan terbukti siapa saja yang yang benar pengakuannya dan siapa pula yang dusta. Problematika yang dihadapi para aktivitas dakwah di medan dakwah terlalu banyak untuk disebutkan satu persatu. Di sini akan kami diungkapkan beberapa hal yang sering dijumpai dalam kehidupan sehari-hari, dan merupakan kendala yang bersifat internal, yaitu gejolak kejiwaan, ketidak seimbangan aktivitas, latar belakang dan masa lalu, penyesuaian diri. Belajar dari hal tersebut, para aktivis dakwah harus mampu menyesuaikan dan mengelola kendala internal dalam dirinya terlebih dahulu, agar bisa optimal menunaikan amanah dakwah. Ada beberapa hal dalam problematika internal aktivis dakwah : Gejolak Kejiwaan para aktivis dakwah adalah manusia biasa yang lengkap seluruh unsur kemanusiaannya. Wajar jika mereka memiliki permasalahan kejiwaan. Mereka bisa merasakan sedih, senang, kecewa, dan bangga. Bahkan, terkadang bingung, cemas, gelisah, marah, namun ada saat tenang dan gembira. Di dalam diri manusia terdapat ada banyak potensi yang mengarahkan kepada kebaikan manusia, namun ada juga yang mengarah pada potensi yang membawanya kepada keburukan, dengan demikian tergantung dari masing-masing manusia dalam 
mengalokasikan potensi tersebut. Sebagai manusia biasa, setiap aktivitas dakwah memiliki peluang untuk mengalami berbagai gejolak dalam dirinya. Jika tidak dikelola secara tepat, maka gejolak ini bisa bedampak negative dalam kegiatan dakwahnya, bahkan dalam kondisi tertentu bisa menghancurkan citra aktivitas dan dakwah itu sendiri.

Ujian tersebut sesunggunya diperlukan oleh orang-orang mukmin justru untuk meningkatkan kapasitasnya. Adanya ujian dan kendala-kendala riil ditengah kehidupan ini akan terbukti siapa saja yang yang benar pengakuannya dan siapa pula yang dusta. Problematika yang dihadapi para aktivitas dakwah di medan dakwah terlalu banyak untuk disebutkan satu persatu. Di sini akan kami diungkapkan beberapa hal yang sering dijumpai dalam kehidupan sehari-hari, dan merupakan kendala yang bersifat internal, yaitu gejolak kejiwaan, ketidak seimbangan aktivitas, latar belakang dan masa lalu, penyesuaian diri. Belajar dari hal tersebut, para aktivis dakwah harus mampu menyesuaikan dan mengelola kendala internal dalam dirinya terlebih dahulu, agar bisa optimal menunaikan amanah dakwah. Ada beberapa hal dalam problematika internal aktivis dakwah :

a. Gejolak Kejiwaan, Para aktivis dakwah adalah manusia biasa yang lengkap seluruh unsur kemanusiaannya. Wajar jika mereka memiliki permasalahan kejiwaan. Mereka bisa merasakan sedih, senang, kecewa, dan bangga. Bahkan, terkadang bingung, cemas, gelisah, marah, namun ada saat tenang dan gembira. Di dalam diri manusia terdapat ada banyak potensi yang mengarahkan kepada kebaikan manusia, namun ada juga yang mengarah pada potensi yang membawanya kepada keburukan, dengan demikian tergantung dari masing-masing manusia dalam mengalokasikan potensi tersebut. Sebagai manusia biasa, setiap aktivitas dakwah memiliki peluang untuk mengalami berbagai gejolak dalam dirinya. Jika tidak dikelola secara tepat, maka gejolak ini bisa bedampak negative dalam kegiatan dakwahnya, bahkan dalam kondisi tertentu bisa menghancurkan citra aktivitas dan dakwah itu sendiri. (Cahyadi, 2002 : 13-17)

b. Gejolak Syahwat, Menurut Cahyadi, banyak potensi syahwat. Sebenarnya syahwat ini merupakan potensi fitrah yang dikaruniakan Allah swt. kepada manusia, namun ternyata banyak manusia yang terpeleset ke dalam jurang kehinaan dan kemaksiatan karena menuruti atau memperturutkan keinginan syahwatnya. Bukan hanya manusia, bahkan para pengemban aktivis dakwah juga memiliki peluang terjebak dalam gejolak syahwat. Allah swt. syahwat sebagai sebuah kenyataan naluriyah, setiap manusia memilikinya: Dijadikan indah pada pandangan manusiakecintaan kepada apa-apa yang diinginkan, yaitu wanita-wanita, anak-anak, harta yang banyak dari jenis emas, perak, kuda pilihan, binatang ternak dan sawah ladang, itulah kesenangan hidup di dunia dan di sisi Allah tempat kembali yang baik / surga (Ali-Imran, 14) Gejolak kejiwaan dalam hal syahwat ini muncul dengan sendirinya tanpa mengenal batas usia, meskipun akan tampak lebih kuat terjadi pada usia muda. Oleh karena itu bagi aktivis dakwah atau juru dakwah, gejolak ini harus ditanggapi dengan serius, sebab apabila dibiarkan akan dapat menimbulkan kecendrungan yang bisa menjerumuskan. (Cahyadi, 2002 : 13-17).

c. Gejolak Amanah. Kadang gejolak jiwa di sisi yang lain muncul ketika menangani kasuskasus medan dakwah. Permasalahan dakwah sering memancing munculnya gejolak kemarahan dalam jiwa para aktivis dakwah, yang jika tak terkendali akan memunculkan letupan, baik berupa ucapan maupun perbuatan. Pada kondisi seperti ini, perasaan yang 
lebih dominan, pertimbangan akal sehat bahkan perhitungan manhaj dakwah menjadi terabaikan. Tentu saja hal ini merupakan peluang bagi munculnya penyimpangan manhajiyyah dalam gerak dakwah, sekaligus membuka celah tak menguntungkan bagi kondisi juru dakwah itu sendiri. Kadang-kadang gejolak kejiwaan yang muncul pada diri juru dakwah dalam melihat suatu keadaan, baik di medan dakwah maupun pad penataan gerak dakwah itu, membuka peluang kearah terjadinya fitnah di kalangan muslim sendiri. Apabila gejolak ini tidak segera diselesaikan, bisa menimbulkan kereawanan hubungan yang membahayakan gerakan dakwah itu sendiri. Di sini tampak peranan penting seorang juru dakwah dalam menyyelesaikan gejolak tersebut. Satu sisi akan memberikan peringatan, bahkan bisa jadi berupa hukuman kepada person yang melanggar. Sementara, di sisi lain mampu menyelesaikan urusan akibat gejolak yang muncul. (Cahyadi, 2002 : 13-17).

d. Gejolak Hiroismed. Kadang dijumpai sebuah semangat yang sangat heroik di medan perjuangan, apabila tatkala berada dalam peperangan menghadapi musuh. Semangat kuat yang muncul dari sikap heroisme para petarung adalah mengalahkan dan menahlukan musuh. Pada titik tertentu bahkan itu menjadi semacam obsesi kepahlawanan. Namun jika gejolak ini tidak diletakkan secara tepat, bisa pula berdampak negatif. (Cahyadi, 2002: 13-17).

e. Gejolak Kecemburuan. Kita ingat kisah pembagian harta rampasan pada Perang Hunain. Sesuai perang Hunain, Rasulullah membagi-bagikan harta rampasan kepada yang berhak secara adil dan bijaksana. Namun, Abu Sufyan bin Harb, tokoh penentang islam sejak awal dakwah di Makkah telah mendapat bagian 100 ekor unta dan 40 uqiyah perak. Demikian pula Yazid dan Mu'awiyah, dua orang anak Abu Sufyan mendapat bagian yang sama dengan bapaknya. Kepada tokoh-tokoh yang Quraisy yang lain beliau memberikan bagian 100 ekor unta. Ada pula yang mendapat bagian lebih sedikit dari itu, sehingga seluruh harta rampasan habis dibagi-bagikan. Melihat pembagian itu, muncullah gejolak kecemburuan sampai-sampai sahabat Anshar berkata, "Mudah-mudahan Allah memberikan ampunan kepada Rasul-Nya karena beliau sudah membagi-bagikan dan member kepada orang Quraisy dan tak memberi kepada kami, padahal pedang-pedang kami yang meneteskan darah-darah mereka. Sebenarnya sikap yang ditunjukkan oleh sahabat anshar dalam pembagian harta rampasan atau ghanimah itu sebenarnya lebih disebabkan karena perasaan takut kehilangan perhatian Rasulullah, bukan sekadar karena tak mendapatkan bagian. Namun akhirnya mereka sadar bahwa cara pembagian Rasulullah atau lebih berdasar karena strategi dakwah beliau menghadapi orang orang yang baru masuk islam atau melunakkan hati mereka yang dulu amat keras menghambat gerak dakwah Islam. (Cahyadi, 2002 : 13-17)

\section{Pengertian dan Tantangan Dakwah Era Milenial}

Generasi milenial ialah (juga dikenal sebagai Generasi Y atau Generasi Langgas) adalah kelompok demografi setelah Generasi X. Para ahli dan peneliti biasanya menggunakan awal 1980-an sebagai awal kelahiran kelompok ini dan pertengahan tahun 1990-an hingga awal 2000-an sebagai akhir kelahiran (Wikipedia). 
Kaum muda adalah mereka yang menginjak usia produktif, usia 16-30 tahun, ada pula yang menyebutkan 40 tahun ke bawah. Bisa dikatakan pada usia itulah, kaum muda menginjak usia seseorang mahasiswa dan sarjana-sarjana yang segar. Apa maksud dari semua ini? Di masa inilah tingkat idealisme sebagai mahasiswa sangat tinggi untuk berkiprah di masyarakat. Karena kaum mudalah, bangsa Indonesia bisa makin maju.

Pada zaman ini, terjadi perkembangan media yang signifikan. Perkembangan media baru sebenarnya merujuk pada perubahan dalam proses produksi media, distribusi, dan penggunaan. Media baru tidak terlepas dari aspek digitality, interactivity, hypertextuality, dispersal, dan virtuality. Dalam konsep digitality semua proses media digital diubah (disimpan) ke dalam bilangan, sehingga keluarannya (output) dalam bentuk sumber online, digital disk, atau memory drives yang akan diubah dan diterima dalam layar monitor atau dalam bentuk hardcopy.

Konsep interactivity merujuk kepada adanya kesempatan di mana teks dalam media baru mampu memberikan users untuk write back into the text. Sedangkan konsep dispersal media baru lebih kepada proses produksi dan distribusi media menjadi decentralised dan mengandalkan keaktifan individu (highly individuated) (M Habibi dalalm Jurnal "Optimalisasi Dakwah Melalui Media Sosial di Era Milenial”).

Gawai, internet, dan media sosial menjadi perangkat penting anak muda zaman sekarang. Maka dari itu, salah satu dakwah di era milenial ini Muhammadiyah telah mengeluarkan panduan akhlak dalam beraktivitas di media sosial. Warga Muhammadiyah diharapkan mengindahkan dan melaksanakan serta mengampanyekan panduan ini (dikutip dari akun Facebook, Alim). Isi dari dakwah virtual ini ialah dilarang melakukan gibah, bullying, menyebarkan pornografi, menyebarluaskan hoax, menyebarkan konten yang benar, tetapi tidak sesuai dengan tempat atau waktunya.

Habibi menyebutkan, era milenial menuntut kecepatan dan kemudahan dalam mengakses informasi. Sementara dakwah belum seutuhnya memanfaatkan ragam media yang terus berkembang. Untuk itu, perlu optimalisasi komunikasi dakwah melalui pemanfaatan media baru (new media), utamanya media sosial, mengingat segmentasi mad'u sangat komplek jika ditinjau dari berbagai sisi.

Perlu diketahui oleh kaum muda, pada era milenial ini dakwah secara langsung ataupun tidak langsung menjadi suatu kebutuhan. Karena yang kita ketahui sudah banyak ajaran melenceng dan bercampur masuk ke dalam agama Islam dan menggunakan metode dakwah. Maka dari itu, sebagai kaum muda yang berintelektual dan penerus bangsa, kita harus bisa menjamah hal-hal seperti itu.

Membangun paradigma untuk para mahasiswa di era milenial dengan metode dakwah secara langsung, seperti diskusi mingguan atau pengajian di masjid, kurang mendapat respons. Mahasiswa zaman now lebih mementingkan gaya hedonismenya dibanding membangun paradigma menjadi kaum intelektual. Organisasi dakwah kampus sering sekali mengagendakan kajian keislaman dan diskusi, tetapi minim respons. Padahal, perlu diketahui bahwa dalam Islam kita tidak dibolehkan meninggalkan kaum 
yang lemah di belakang kita. Maksudnya kita harus terus membentuk paradigma kaum intelektual penerus bangsa ini dengan baik.

Sebagai penutup ingatlah selalu Al-Quran surah an-Nisa ayat 9 berikut: "Dan hendaklah takut kepada Allah orang-orang yang seandainya meninggalkan di belakang meraka anak-anak yang lemah, yang mereka khawatir terhadap (kesejahteraan/masa depan) mereka. Oleh sebab itu, hendaklah mereka bertakwa kepada Allah dan hendaklah mereka mengucapkan perkataan benar."

\section{Kesimpulan}

Setelah memaparkan isi dari tulisan ini dapat ditarik kesimpulan bahwa dakwah bertujuan mengajak manusia untuk menegakkan amar maruf dan nahi mungkar, dan dakwah merupakan seruan atau ajakan kepada keinsyafan setiap manusia dan usaha dai mengubah situasi yang lebih baik dan sempurna baik terhadap pribadi maupun masyarakat. Realitas dakwah islam menjadi problem keagamaan yg krusial dan dilematis, bila mengamati dawah islam diera milenial yang teknologinya semakin canggih, seperti sekarang ini tantangan milenial, pada era ini terjadi perkembangan media yang signifikan yang mengajuk pada media baru dari aspek digitaily interactivity, hyper- textuaclity, hyper textecuality, dispersal dan vertuality, gawai, internet, dan media social menjadi perangkat penting bagi manusia milenial.

Membangun paradigma untuk para manusia di era milenial dengan metode dakwah secara langsung, seperti diskusi mingguan atau pengajian di masjid, kurang mendapat respons. zaman now lebih mementingkan gaya hedonismenya dibanding membangun paradigma menjadi kaum intelektual. Organisasi dakwah sering sekali mengagendakan kajian keislaman dan diskusi, tetapi minim respons. Padahal, perlu diketahui bahwa dalam Islam kita tidak dibolehkan meninggalkan kaum yang lemah di belakang kita. Maksudnya kita harus terus membentuk paradigma kaum intelektual penerus bangsa ini dengan baik. 


\section{DAFTAR PUSTAKA}

Ahmad ,Amrullah. 1983.Dakwah Islam dan Perubahan Sosial,Primaduta Yogyakarta.

Ahmad ,Amrullah. 1983.Dakwah Islam dan Perubahan Sosial,Primaduta Yogyakarta.

Ansyari, Isa. 1979. Mujahid Dakwah ; Pembimbing Mubaliq Islam. CV. Dipenogoro , Bandung.

Ayub, Mohammad,1996. Manajemen Masjid (Petunjuk Praktis Bagi Para Pengurus), Jakarta: Gema Insani Press,

Ayyub, Hazan Muhammad. 2007. Fiqhi al-ibadah bi adillatiha fii al-Islam wa fiqhi al-hajj wa al-umrah, terjemahan M. Abdul Ghoffar dan Arif Rahman Hakim, Lc., Panduan Beriadah Khusus Pria; Menjalankan Ibadah Sesuai dengan Tuntunan Al Quran dan As Sunah, Jakarta Timur: Al Mahirah,.

Departemen Agama Republik Indonesia, Al-Quran dan Terjemahannya, Madinah al Munawwarah: Mujammah' al Malikal Fahd Li Thaba'at al Mushaf asy Syarif, $1415 \mathrm{H} / 1995 \mathrm{M}$.

Milenial, diakses pada https://id.wikipedia.org, pada tanggal 10 Februari 2019

Shihab M. Quraish, 1996.Wawasan Al Quran, Tafsif Maudh'i atas pelbagai persoalan umat, Cet. III, (Bandung: Mizan.

Syukir, Asmuni.1983. Dasar-dasar Strategi Dakwah. . Surabaya: Al-Ikhlas.

Yaqub, Hamzah. 1881. Publistik Islam ; Teknik Dakwah dan Leadership. CV. Dipenogoro, Bandung.

Yaqub, Hamzah. 1881. Publistik Islam ; Teknik Dakwah dan Leadership. CV. Dipenogoro, Bandung. 